Editorial

\title{
Space for the Liminal
}

\author{
Valerie Belair-Gagnon ${ }^{1, *}$, Avery E. Holton ${ }^{2}$ and Oscar Westlund ${ }^{3,4,5}$ \\ ${ }^{1}$ Hubbard School of Journalism and Mass Communication, University of Minnesota, Twin Cities, MN 55455, USA; \\ E-Mail:vbg@umn.edu \\ 2 Department of Communication, University of Utah, Salt Lake City, UT 84112, USA; E-Mail: avery.holton@utah.edu \\ 3 Department of Journalism and Media Studies, Oslo Metropolitan University, 0130 Oslo, Norway; \\ E-Mail: oscar.westlund@oslomet.no \\ ${ }^{4}$ Faculty of Media and Journalism, Volda University College, 6103 Volda, Norway \\ ${ }^{5}$ Department of Journalism, Media and Communication, University of Gothenburg, 40530 Gothenburg, Sweden \\ * Corresponding author
}

Submitted: 27 November 2019 | Published: 17 December 2019

\begin{abstract}
This essay considers how social actors in news have come to shape the contours of news and journalism and what these changes may suggest for other industries. It looks more specifically at the question of who does journalism and news and what that may signal for power dependencies, status, and norms formation. It examines how authors who contributed to this thematic issue define who gets to decide what is news and journalism, what forms of power are exerted amongst groups, who gets to claim status, and how norms and epistemologies are formed. Ultimately, this essay illustrates how conformity to groups and organizations varies with the investments that these social actors have to core and more peripheral journalism and media groups.
\end{abstract}

\section{Keywords}

digital journalism; journalism; journalism practice; news production; peripheral actors; sociology of work

\author{
Issue \\ This editorial is part of the issue "Peripheral Actors in Journalism: Agents of Change in Journalism Culture and Practice" \\ edited by Avery E. Holton (University of Utah, USA), Valerie Belair-Gagnon (University of Minnesota-Twin Cities, USA), and \\ Oscar Westlund (Oslo Metropolitan University, Norway / Volda University College, Norway / University of Gothenburg, \\ Sweden).
}

(C) 2019 by the authors; licensee Cogitatio (Lisbon, Portugal). This article is licensed under a Creative Commons Attribution 4.0 International License (CC BY).

\section{Introduction}

Twenty-first century capitalism and globalization involve a proliferation of emerging social actors across a broad swath of industries and professions. These social actors are transforming contemporary work and professions, including news and journalism. While the news media help the public make sense of these changes; they also are undergoing the very shifts they are helping to contextualize (Couldry, in press; Zelizer, 2019).

News and journalism offer a lens into the growing importance of these social actors as well as the perspectives and digital innovations they may help foster in an evolving professional landscape. In the case of news production, sharing, and distribution, there are a number of social actors who occupy a liminal existence adjacent to more established, organizational, and institutional ones. These are often specialty actors who exist in close orbit to larger, often more-established ones, creating a kaleidoscopic structure of work that enables a variety of core and peripheral actors. This occurs at a time also marked by the continued rise of powerful and global platform companies in spaces previously dominated by mass media and news publishers (see Ananny, 2019; Myllylahti, 2019).

Along these same lines, journalism scholars have engaged in continued debates of what journalism is and who journalists are (Tandoc, 2019). A number of scholars 
have questioned the authoritative professional boundaries of journalism, the shrinking autonomy of news organizations, and the changing culture of news production to one that now includes, perhaps less begrudgingly than in the past, emerging social actors (see Carlson, 2017; Tong, 2015; Wahl-Jorgensen, 2019). These are significant questions to consider for journalism as an industry that is seeking ways to improve its financial footing, which is associated with changing professional conditions for news work and, in some cases, conditional autonomy (see Myllylahti, 2019; Nel \& Milburn-Curtis, 2019; Waldenström, Wiik, \& Andersson, 2019). This happens at a time when journalists are also wrestling with a plurality of epistemologies and platforms, authoritative boundaries, and news processes that are becoming more publicly porous (see Mclntyre \& Sobel, 2019). These questions may be applied to the examination and positioning of social actors in global industries, which themselves are experiencing an influx of such workers.

In focusing on news and journalism, and digital journalism more specifically, as a "networked production, distribution, and consumption of news and information about public affairs" (Waisbord, 2019), Waisbord argues that changes brought by digital journalism have resulted in a broadening of what journalism and news are as process and product and who is involved in producing and sharing news. He argues that "virtually anyone with access to the internet can take part in digital journalism" (Waisbord, 2019, p. 352), while acknowledging that there are others questioning such a view. They argue that such social actors are rarely, if ever, journalistic actors because they do not adhere more preeminently to professional journalistic practices, may not chiefly receive income from news organizations, and primarily work outside the professional norms, values, and practices that guide journalism as practice. Yet, the contributions of these social actors, who have been labeled as interlopers and peripheral contributors among other titles, are increasingly more visible in the production and dissemination of news and in audience engagement (see Eldridge, 2017; Holton \& Belair-Gagnon, 2018). Eldridge (2017), for example, argues that payment from news organizations and adherence to journalistic norms are no longer the only qualifications for journalists. Indeed, the label of journalist may be assumed with caution or even rejected by the very individuals who are creating, sharing, or otherwise engaging in acts of news (Holton \& BelairGagnon, 2018).

Today's news may be represented by a blend of traditional journalists, editors, and producers working alongside or concurrently with bloggers, microbloggers, coders, hackers, brand influencers, web metrics developers, civic technologists, and diverse digital innovators (see for example Baack, 2018). To understand the full breadth of social actors involved in the practice of contemporary journalism and different epistemologies of journalism (see Ekström \& Westlund, 2019), as well as other forms of news by alternative news media (Holt,
Figenschou, \& Frischlich, 2019; Keith, 2019), we must look beyond the confining definitions traditionally associated with journalists or journalistic actors.

This thematic issue broadens perspectives and understandings of diverse social actors, organizations, and institutions now involved in news and journalism. This is done at the peril of angels dancing on pinheads, so to speak, because a number of studies have recently taken up considerations of the varying forms of actors, parsing from labels such as outside and peripheral actors to media interlopers to explicit and implicit interlopers and intralopers (see Eldridge, 2017; Holton \& Belair-Gagnon, 2018). This layering of labels and definitions, though, suggests a need for contextualizing a complex set of actors and factors contributing to changes in the processes and power of journalism and related industries that considers, rather than rejects, the importance of nuancing (see Ryfe, 2019).

This thematic issue offers peer-reviewed articles and invited commentaries that help advance and nuance the question of who carries out journalism, or more broadly who participates in journalism. While there has been much debate about this in journalism studies over the years, this is not simply an intra-academic and intellectual exercise. There have also been discourses in the news industry about who journalists are, when an outsider becomes an insider, and what influences such actors might have on news organizations, news audiences, and the institution of journalism (see for example OpenNews, which connects developers, designers, journalists, and editors who, within the organization's settings, can collaborate on open technologies and journalistic processes). While journalists and the news media may continue their attempts to maintain professional boundaries through meta-journalistic discourse (Carlson, 2017), there are also critical discussions about how the registration of journalists as a form of accreditation in some countries calls for criticism from a freedom of expression perspective since this may well lead to control and exclusion (see Posetti, 2017).

\section{Questions of Who}

Just as questions of what journalism is are important exploration areas for journalists, news organizations, and journalism scholars (Eldridge, Hess, Tandoc, \& Westlund, 2019), the question of who does journalism, or the broader question of who does news, is of critical importance for a wide array of stakeholders in journalism. Besides a number of countries in Asia, in most continents the majority of countries experience continue to experience a dated business model of commercial news media that has been broken for some time. Large numbers of news publishers have substantially downsized their operations. Many have filed for bankruptcy or been dissolved into existing companies. News publishers have also been shut down by governments, including authoritarian regimes, essentially censoring the press and strip- 
ping away its democratic voice. UNESCO continuously reports on governmental and other threats, the imprisonment of journalists, and, in some cases, the murder of those who devote their lives to the profession.

Financial and political conditions can raise insurmountable challenges for news and journalism. There are so-called news deserts in many parts of the world, where local and regional news media are absent, as well as self-censored and terrified journalists painfully aware that authorities are surveilling their every step. The latter is made all the worse by the existence of internet trolls who target and manipulate the news media as well as human and automated bots helping create and distribute misinformation and disinformation with the purpose of distracting and discrediting news and journalists (see Ferrier \& Garud-Patkar, 2018; Quandt, 2018).

The broader question of who does news is important to policy makers in different countries: Some countries (most notably in Scandinavia) have subsidies for news publishers and need to have criteria that define who is eligible for support or not. Moreover, many countries have discussed and also set in motion laws that prohibit misinformation and disinformation, or in many cases information that does not align with a government's agenda, giving authorities the right to censor and punish organizational or individual actors who produce or share news they deem inappropriate. Countries such as Indonesia and Germany have enforced regulations with regards to "fake news sites" or platform companies. In Belarus, Malaysia, and Kenya authorities have passed laws forbidding citizens to produce and/or spread misinformation or disinformation. By defining that these are not journalistic actors and associating non-authorized news work with criminality, the challenges of defining who does journalism is critical. This is especially important when it comes to ideals of, and limitations to, free speech.

When political actors or institutional news actors have the power to define who is and is not a journalist, they set conditions for who can exercise journalism. In some countries in Asia, the Middle East, and beyond, the authorities delegate power to an industry association to be in charge of who gets the formal recognition to work as a journalist. Their board of directors receive application letters, where support from institutional news media is necessary, and interview and assess applicants. The authorities and the association can this way make sure that the journalists fall in line and do not create problems by criticizing those in power. Ultimately, this means that journalists directly or indirectly can be forced to change their coverage to align with the views of their oppressors.

Institutional belonging to news media is seminal for journalists in many countries, as the press pass is a necessary symbol of journalistic authority, enabling them to gain access into reporting spaces. Indeed, in some countries, governments are actively involved in defining who is recognized as a journalist and receives a press pass, which may well be necessary to get access to cer- tain spaces, such as events and sources (Carlson, 2017; Hermes, Wihbey, Junco, \& Aricak, 2014). Different conditions clearly apply in different countries. There are several countries, such as Brazil, Nicaragua, and the United States, where national political leaders repeatedly communicate via social media that the journalists and the news media are enemies of the people, produce misinformation and disinformation, and should not be trusted. They then engage in "fake news labeling," which means that they use the term "fake news" to delegitimize news media and journalists (Egelhofer \& Lecheler, 2019).

The question of defining journalists also connects with issues of resources and support: having peers to coordinate with to validate information and coverage, having technical infrastructures and tools, having insurances, and so forth. In many countries, this goes hand in hand with working for news institutions that have editors-inchiefs who can be held accountable either by outside institutions or government agencies. In Sweden, for example, the news media must have a certified editor-inchief in their established news organizations, and their journalists, are to offer legal protection for their sources in line with Swedish laws. However, there are no higher education degrees or other professional qualifications that the Swedish state requires of journalists in order for them to perform work as journalists. Ultimately, news organizations can recruit people with formal journalism education and others without, such as computer scientists with relevant tacit knowledge or a political scientist with worthwhile explicit knowledge of the field. There is much heterogeneity across the world when it comes to legal conditions governing who is a journalist, having the permission and resources to carry out journalism and publish news, and who is restricted from the practice. More precisely, authorities in some countries give bloggers the same status as journalists and outright forbid blogging or microblogging that orients toward journalism in others. This extends to acts associated with journalism such as whether to permit live communications (blogging or micro-blogging) from courtrooms or not (Johnston \& Wallace, 2017).

Defining who is a journalist is also relevant to ordinary citizens who develop their news literacy about what journalists and what news publishers they feel they can trust to deliver and contextualize information about the world around them. Defining who is a journalist, or what is news, is also important in relation to sponsored editorial content such as native advertising. Such blending of news-oriented and advertising information extends to platform companies such as Facebook, Twitter, Instagram, and YouTube, which implement criteria as to who and what gets more exposure. Their choices and algorithms influence many stakeholders, including the very audiences they initially set out to serve and to connect with reliable content. As news organizations continue to search for ways to maintain or relinquish authority in these and other digital spaces, issues of power, status, and the formation of new norms arise. 


\section{Power Dependencies, Status, and Norms Formation}

Once observed and defined, the question of who is a journalist or part of the constellation of journalistic actors raises questions of who gets to define what is news and journalism, what forms of power dependencies are exerted amongst groups, who gets to claim status, and how are norms and epistemologies formed. In an early sociological account of power, institutions, and legitimacy of small and more complex community group organizations, Emerson (1962, p. 32) contended that "social relations commonly entail ties of mutual dependence between the parties." Power through this perspective can be understood in terms of relationships between two or more actors: to what extent A depends on $B$ to do what needs to be done. Its applicability is wide-ranging as it encompasses in what ways individual journalists are dependent on social actors such as other journalists, editors, technologists, or automated algorithms both inside and outside newsrooms. This approach also involves institutional levels of dependence, such as how news publishers depend on platform companies for eye balls, metrics, and revenue streams (see Nel \& Milburn-Curtis, 2019). Moreover, power dependencies as an analytical category also applies to the overall relationship between journalism and technology or journalism and politics, among others.

Power dependencies work hand in hand with resistance among a set of actors, which define the norms and practices of a stated organization. Resistance, Emerson (1962) argued, emerged from the dependencies among the set of different actors. For example, in this issue, in focusing on interlopers' reactions to traditional journalism, Eldridge's essay (2019) proposes that scholars and practitioners continue to see the journalistic field as complex and interwoven in core-periphery differentiation processes. As Eldridge (2019) suggests, societal distinction matters both for interlopers and traditional journalists, sometimes for interlopers the criticism is being conceived as a way to enhance the broader field of journalism. Relatedly, Schapals, Maares, and Hanusch (2019) show how certain groups of actors that may not have originally defined themselves as journalists while "working on the margins" discursively differentiate their work from others. Though, the authors warn us, these social actors claim to engage in journalism from an altruistic perspective that is deeply rooted in an ideology of journalism pre-crisis era, "one which sees journalism as serving a public good by providing an interpretative, sensemaking role" (Schapals, Maares, \& Hanusch, 2019, p. 19).

Importantly, the notion of reciprocity in these power dependencies relations "raises the question of equality or inequality of power in the relation" (Emerson, 1962, p. 33). There is a well-documented tension between professional journalists on the one hand, and citizen journalists and/or audiences that potentially can be approached as active participants and contributors in the making of news on the other hand (e.g., Akinfemisoye, 2014). Indeed, in deploying a systematic literature review of on- line participatory journalism, while noting continuity and change in research, Engelke (2019) shows how "power structures differ depending on the examined world region, production stage, and actor perspective" (p. 31). Similarly, Ferrucci and Nelson (2019) qualify the philanthropic foundations who seek helping journalism to find economic stability as "new advertisers." In forming these coalitions, the two authors note that these philanthropic foundations have an influence on editorial decisions similar to those that advertisers have had. Such power dependencies relations may lead to more "skewed power dynamic..., one where journalists cede agency to elite foundations situated outside the boundaries of journalism" (Ferrucci \& Nelson, 2019, p. 46).

Hepp and Loosen (2019) also present the development and conceptualization of molo.news. They demonstrate the relationality of the stakeholders' figurations involved in the development of a prototype as relational boundary object and the relational concept of the platform, chiefly as a "space of possibility" (Hepp \& Loosen, 2019) and emerging local news forms. Braun, Coakley, and West (2019) additionally examine an international activist movement and contend that the trajectory of these digital activists evolved into value statements that became boundary objects. They argue that journalists working for the digital activist organization increasingly borrow from advertising practices in the local and cultural context of the web in which they emerged.

Taken into account in power dependencies, there are cost reduction and coalition formation dynamics that need to be nuanced. For example, Haim and Zamith (2019) evaluate a set of active accounts and their repositories on a code-sharing platform. They argue that the code-sharing platform provides a space for actors associated with the periphery of journalism through a platform that restrict the ability of these "outsiders" to move their ideas from the periphery to the center. In other words, Haim and Zamith (2019) see these power dependencies as "a missed opportunity for traditional journalistic actors to use code-sharing platforms to work with motivated technological actors in order to develop more innovative actants or more transformative reconfigurations of the field" (p. 81).

Using a case study of a North American not-for-profit digital-born news organization, Hermida and Young (2019) explore a complex journalism actor that operates across individual, organizational, and network levels. They show how such social actors can benefit from the crisis of journalism. In doing so, Hermida and Young (2019) allude that these social actors may foster an emerging set of group norms (i.e., 'specifications of behavior which all group members expect of all group members') and role-prescriptions (i.e., 'specifications of behavior which all group members expect-or demandof one or more but not all members') to news and journalism across multiple domains of the journalistic process, including production, publication, and dissemination. Indeed, for Hermida and Young (2019), to facili- 
tate the function of journalism and news, not all actors may perform the same actions. In other words, together, these actors may foster a division of labor in a role structure and these roles may be defined and enforced through the amalgamation of power in coalition formation (Hermida \& Young, 2019).

The assumed levels of dependencies between these social actors may contribute to the rise in status of these actors in the complex networks in which they inhabit and what ultimately constitutes the information ecosystem by which society defines and redefines itself. In a commentary, Ahva (2019) proposes to look at journalism as a community of practice and unpacks the relevance of practice theory. By studying concrete practices, Ahva (2019) argues that scholars and practitioners can identify the social actors involved and how they depend on each other. In a call to bring the Global South into conversations with peripheral journalism studies, and particularly journalism in African countries, Wahutu's commentary (2019) explores how actors may still exist in liminal spaces and causes challenges in their emergence in status. Wahutu (2019) suggests that the negotiations of class, race, and gender allow/facilitate interaction amongst actors. These negotiations of their liminality may subject these actors have a lack of status and may be denied access in status hierarchy to achieve their goals or simply to gain legitimacy to the core or from the periphery.

Conversely, and in drawing from a practice theory inspired ethnographic study with three newsrooms, Konow-Lund (2019) proposes that networks of social actors involved in global investigative stories are creating emerging epistemologies, norms, values, and practices unique to their act of coordination. Likewise, Chua and Duffy (2019) show that there is a growing salience of hybrid roles in Singaporean legacy news media that serve as "linchpins to connect divergent professional fields" and "bridges between tradition and innovation" (p. 112). For the two scholars, four forms of proximity (i.e., physical, temporal, professional, and control) help develop understandings of the impact that peripheral players may have on innovation in news organizations.

\section{Conclusion}

In each of these articles and commentaries, the who these actors are becomes a question of how they are intertwined in journalism and for what purposes and effects. The original articles and invited commentaries in this thematic issue points to ties that bind together these emerging social actors who have become and continue to become part of the news and journalism social ecosystem. Individually and collectively, these social actors bring hybrid and new meanings as well as normative expectations to truth, facts, newsgathering, journalistic epistemologies, norms, values and practices that have shaped and are shaping contemporary news and journalism (Singer, 2019).
Yet, as this issue complexly suggests, conformity to groups and organizations varies with the investments that these social actors have to the core and more peripheral journalism and media groups. History has shown that those who are more valued in such groups tend to adhere more closely to core epistemologies, norms, values, and practices (see Emerson, 1962). That may be changing, though, as the liminal become more visible and more significant across a multitude of industries. Journalism is but one professional landscape to examine how the traditional who of the industry is changing and how those shifts impact the very foundations of its institution.

\section{Acknowledgments}

We would like to acknowledge the many reviewers who contributed to this issue, the editors for their assistance and guidance, and the authors who contributed to this thematic issue and allowed us to be part of their process. We would also like to thank Volda University College for supporting us in organizing the symposium "Professional and Peripheral News Workers and the Shifting Importance of Platforms" in June 2019. The symposium and all of the participants contributed to shaping many of the articles published in this issue. Oscar Westlund ackowledges his Adjunct Professor position at Volda University College for enabling his contributions as guest editor.

\section{Conflict of Interests}

The authors declare no conflict of interests.

\section{References}

Ahva, L. (2019). About actor positioning in journalism, slowly. Media and Communication, 7(4), 123-126.

Akinfemisoye, M. O. (2014). Negotiating convergence. Digital Journalism, 2(1), 62-76.

Ananny, M. (2019). Tech platforms are where public life is increasingly constructed, and their motivations are far from neutral. Nieman Lab. Retrieved from https:// www.niemanlab.org/2019/10/tech-platforms-arewhere-public-life-is-increasingly-constructed-andtheir-motivations-are-far-from-neutral

Baack, S. (2018). Practically engaged. Digital Journalism, 6(6), 673-692.

Braun, J. A., Coakley, J. D., \& West, E. (2019). Activism, advertising, and far-right media: The case of sleeping giants. Media and Communication, 7(4), 68-79.

Carlson, M. (2017). Journalistic authority: Legitimating news in the digital era. New York, NY: Columbia University Press.

Chua, S., \& Duffy, A. (2019). Friend, foe or frenemy? Traditional journalism actors' changing attitudes towards peripheral players and their innovations. Media and Communication, 7(4), 112-122. 
Couldry, N. (in press). Media: Why it matters. Cambridge: Polity Press.

Egelhofer, J. L., \& Lecheler, S. (2019). Fake news as a two-dimensional phenomenon: A framework and research agenda. Annals of the International Communication Association, 43(2), 97-116.

Ekström, M., \& Westlund, O. (2019). The dislocation of news journalism: A conceptual framework for the study of epistemologies of digital journalism. Media and Communication, 7(1), 259-270.

Eldridge, S. A., II. (2017). Online journalism from the periphery: Interloper media and the journalistic field. London: Routledge.

Eldridge, S. A., II. (2019). Where do we draw the line? Considering cores and peripheries and the limits of an unbounded journalistic field. Media and Communication, 7(4), 8-18.

Eldridge, S. A., II, Hess, K., Tandoc, E. C., Jr, \& Westlund, O. (2019). Navigating the scholarly terrain: Introducing the digital journalism studies compass. Digital Journalism, 7(3), 386-403.

Emerson, R. M. (1962). Power-dependence relations. American Sociological Review, 27(1), 31-41.

Engelke, K. M. (2019). Online participatory journalism: A systematic literature review. Media and Communication, 7(4), 31-44.

Ferrier, M., \& Garud-Patkar, N. (2018). TrollBusters: Fighting online harassment of women journalists. In J. R. Vickery \& T. Everbach (Eds.), Mediating misogyny: Gender, technology, and harassment (pp. 311-332). Cham: Springer. https://doi.org/10.1007/978-3-31972917-6_16

Ferrucci, P., \& Nelson, J. L. (2019). The new advertisers: How foundation funding impacts journalism. Media and Communication, 7(4), 45-55.

Haim, M., \& Zamith, R. (2019). Open-source trading zones and boundary objects: Examining GitHub as a space for collaborating on "news." Media and Communication, 7(4), 80-91.

Hepp, A., \& Loosen, W. (2019). Molo.news: Experimentally developing a relational platform for local journalism. Media and Communication, 7(4), 56-67.

Hermes, J., Wihbey, J., Junco, R., \& Aricak, O. (2014). Who gets a press pass? Media credentialing practices in the United States (Working Paper No. 2014-11). Cambridge, MA: The Berkman Klein Center for Internet \& Society at Harvard University. https://doi.org/ 10.2139/ssrn.2451239

Hermida, A., \& Young, M. L. (2019). From peripheral to integral? A digital-born journalism not for profit in a time of crises. Media and Communication, 7(4), 92-102.

Holt, K., Figenschou, T. U., \& Frischlich, L. (2019). Key dimensions of alternative news media. Digital Journalism, 7(7), 860-869.

Holton, A. E., \& Belair-Gagnon, V. (2018). Strangers to the game? Interlopers, intralopers, and shifting news production. Media and Communication, 6(4), 70-78.

Johnston, J., \& Wallace, A. (2017) Who is a Journalist?
Digital Journalism, 5(7), 850-867.

Keith, S. (2019). Literary journalism and alternative media. In W. E. Dow \& R. S. Maguire (Eds.), The Routledge companion to American literary journalism (pp. 183-198). New York, NY: Routledge. https://doi.org/ 10.4324/9781315526010-13

Konow-Lund, M. (2019). Negotiating roles and routines in collaborative investigative journalism. Media and Communication, 7(4), 103-111.

McIntyre, K., \& Sobel, M. (2019). How Rwandan journalists use WhatsApp to advance their profession and collaborate for the good of their country. Digital Journalism, 7(6), 705-724.

Myllylahti, M. (2019). Paying attention to attention: A conceptual framework for studying news reader revenue models related to platforms. Digital Journalism. Advance online publication. https://doi.org/10. 1080/21670811.2019.1691926

Nel, F., \& Milburn-Curtis, C. (2019). Towards a global measure to map and monitor a sustainable media ecosystem. Paper presented at Emma Conference 2019, Limassol, Cyprus. Retrieved from https://www.media-management.eu/ocs/index.php/ emma/emma2019/paper/viewPaper/1002

Possetti, J. (2017). Time to step away from the "bright, shiny things'? Towards a sustainable model of journalism innovation in an era of perpetual change. Reuters Institute. Retrieved from https://reuters institute.politics.ox.ac.uk/our-research/time-stepaway-bright-shiny-things-towards-sustainablemodel-journalism-innovation-era

Quandt, T. (2018). Dark participation. Media and Communication, 6(4), 36-48.

Ryfe, D. (2019). The warp and the woof of the field of journalism. Digital Journalism, 7(7), 844-859.

Schapals, A. K., Maares, P., \& Hanusch, F. (2019). Working on the margins: Comparative perspectives on the roles and motivations of peripheral actors in journalism. Media and Communication, 7(4), 19-30.

Singer, J. B. (2019). Populist postmodernism: When cultural critique of an enlightenment occupation goes viral. Media and Communication, 7(4), 133-137.

Tandoc, E. C., Jr. (2019). Journalism at the periphery. Media and Communication, 7(4), 138-143.

Tong, J. (2015). Chinese journalists' views of usergenerated content producers and journalism: A case study of the boundary work of journalism. Asian Journal of Communication, 25(6), 600-616.

Wahl-Jorgensen, K. (2019). Emotions, media and politics. Hoboken, NJ: John Wiley \& Sons.

Wahutu, J. S. (2019). Prophets without honor. Media and Communication, 7(4), 127-132.

Waisbord, S. (2019). The $5 \mathrm{Ws}$ and $1 \mathrm{H}$ of digital journalism. Digital Journalism, 7(3), 351-358.

Waldenström, A., Wiik, J., \& Andersson, U. (2019). Conditional autonomy. Journalism Practice, 13(4), 493-508.

Zelizer, B. (2019). Why journalism is about more than digital technology. Digital Journalism, 7(3), 343-350. 


\section{About the Authors}

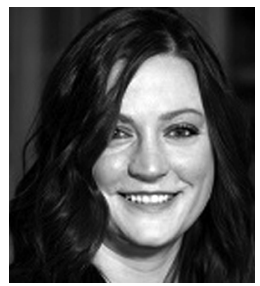

Valerie Belair-Gagnon (PhD) is Assistant Professor of Journalism Studies at the Hubbard School of Journalism and Mass Communication and is affiliated faculty in the Department of Sociology at the University of Minnesota. She also is affiliated fellow at the Yale Law School Information Society Project.

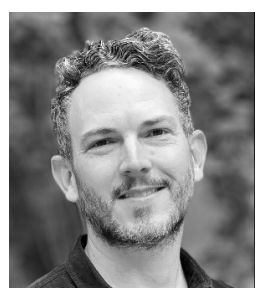

Avery E. Holton is an Associate Professor and Vice-President's Clinical and Translational Scholar at the University of Utah, where he also serves as the University's Student Media Advisor. Working out of the Department of Communication, and in coordination with the Honors College, his research and project developments focus on the intersections of journalistic identity, misinformation, digital and social media, and broader issues of health communication. He was selected as a 2018 National Humanities Center Summer Fellow for his explorations of artificial intelligence in journalism and in healthcare settings and served in 2019 as an Oslo Metropolitan Digital Journalism Research Fellow in Oslo, Norway. He serves on six editorial boards, including Journalism, Health Communication, and the Journal of Broadcasting and Electronic Media. He has published more than 70 peer-reviewed journal articles, book chapters, and encyclopedia entries in journals such as Communication Theory, Journalism, Journalism Studies, and New Media \& Society.

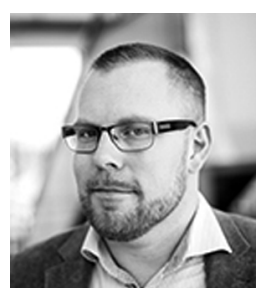

Oscar Westlund (PhD) is Professor at the Department of Journalism and Media Studies at Oslo Metropolitan University, where he leads the OsloMet Digital Journalism Research Group. He holds secondary appointments at Volda University College and University of Gothenburg. Westlund specializes in digital journalism studies, media management and mobile media and communication, fields in which he has published widely, and also co-authored books and reports for the EU commission and the Government offices of Sweden. Westlund has edited special issues for six different international journals, and is the Editor-in-Chief of Digital Journalism. He currently leads a research project called the epistemologies of digital news production, funded by the Swedish Foundation for Humanities and Social Sciences. 